\title{
Dynamic Linkages between Mobile Money and Banks' Performance in Nigeria: An Autoregressive Distributed Lag (ARDL) Approach
}

\author{
Nkemdilim Iheanachor ${ }^{1}$ \\ *Azuka Elvis Ozegbe ${ }^{2}$ \\ 'Lagos Business School, Lagos, ligeriia \\ 2Iept. of Lconomicos, Ligoss State Iniversity, Lagos, ligeriia
}

\begin{abstract}
This study investigated the relationship between mobile money and Nigerian banks with the purpose of ascertaining if forward and backward causal linkages exist and the direction of causation between the two variables. This inquiry was motivated by the inherent challenges of a low level of awareness, enrolment and utilization of mobile money services in Nigeria despite the efforts of the government to replicate East Africa's success story in Nigeria. This study employed econometric techniques such as the modern autoregressive distributed lag (ARDL) model and Wald causality to respectively assess the relationship between the explained and explanatory variables and the direction of causality between mobile money and various banks' performance metrics using quarterly time series data between 2014 and 2018. The empirical results revealed that there is a causal but insignificant relationship between mobile money and banks' performance indicators, such as profit before tax and total assets. On the premises of the empirical findings, the study concludes that mobile money has forward and backward linkages with banks' performance in Nigeria. This implies that Nigeria's mobile money market as presently constituted does provide attractive incentives for banks to leverage on in their quest to improve performance.

Keywords: Mobile money, bank performance, Wald causality test, $A R D L$, Nigeria

JEL : C1, C12, E44
\end{abstract}

The emergence of mobile money as a means of conducting formal financial transactions swept across many regions of the world, especially that of developing economies (Saal, Starnes and Rehermann, 2017). Scholars (Chiu, Chen and Chen, 2017; Gosavi, 2018; Vincent and Evans, 2019) view the concept of mobile money through different lenses and from various perspectives. Mobile money is generally known as financial transaction services potentially available to anyone owning a mobile device such as phones, including the unbanked global poor who are not a profitable target for commercial banks. The individual user installs a mobile phone application on a SIM card, start up an online or electronic money account with the mobile money services provider (usually referred to as mobile network operators (MNOs) acting alone or in informal alliances with one or more banks, depending on the jurisdiction in a given country), and deposits cash in exchange for electronic money. 
The electronic money can be stored, withdrawn as cash, or transferred via a coded secured text message to others, without the customer or the recipient having a formal bank account depending on the model adopted in the country (Pelletier, Khavul and Estrin, 2016).

The study is motivated by the low level of awareness, enrolment and utilization of mobile money services. Although the Nigerian government put significant efforts on sustainable mobile money services, only 1 percent of her adult population is active users of mobile money, and only 12 percent are aware of its existence (Lepoutre and Oguntoye, 2018). As such, this study used Teece's (1997) dynamic capabilities theory to investigate the causal linkage between mobile money and bank performance using four selected Nigerian banks as the sample. The dynamic capability theory explains how firms adapt to environmental dynamism by modifying their underlying resources and capabilities. It emphasizes the need to identify opportunities and threats within and outside their environment, exploit such opportunities to drive performance as well as maintain competitiveness through enhancing, combining, protecting, and when necessary reconfiguring the business enterprises intangible and tangible resources (Teece, Pisano and Shuen,1997).

Additionally, mobile money and corporate performance relationship is an emerging research space, particularly in frontier economies. Although there are existing studies on mobile money, evidence abounds of inherent limitations even though some have contributed to knowledge in this area. One of such limitations is the lack of causality testing between mobile money and banks' performance. For instance, David-West, Iheanachor and Umukoro (2019b) studied mobile money, banks' performance and sustainable business models. Also, Okeke and Eze (2018) explored mobile money adoption and sustainable business models in Nigeria. Both studies completely ignored the roles of causality in their analyses. The existence or otherwise of forward-backwards linkages is essential to build sustainable models dealing with mobile money and banks' performance. To close these gaps and improve on the limitations of these previous studies this study built its hypotheses on the dynamic capability theory (Teece et al., 1997). Lepoutre and Oguntoye (2018) carried out a comparative historical analysis of the emergence of mobile money between Nigeria and Ghana. Their analysis left out the causality test. David-West, Aluko and Adetunji (2019a) explored the efficacy of mobile money as a panacea for financial exclusion in emerging markets without considering the possibility of a forward-backwards linkage (causality) between mobile money and financial institutions. Other studies (Islam, Muzi and Meza, 2018; Munyegera and Matsumoto, 2016; Okello et al., 2018) are limited correspondingly after neglecting a feedback mechanism between mobile money and financial inclusion. The choice of causality test as the estimation tool for this study based on its appropriateness in analyzing financial data which are widely known to be non-stationary (Erdem and Tugcu, 2012; Sunde, 2017). 


\section{Iheanachor \& Ozegbe}

The contribution of this study to knowledge is threefold. Firstly, it extends earlier studies on mobile money and financial institutions (See David-West et al., 2019a; Islam et al., 2018; Lepoutre and Oguntoye, 2018) by incorporating the causal analytical dimension which helps financial institutions to determine if there is a lead-lag linkage between mobile money and their financial performance. Second, the study validates the tenets of dynamic capability using Nigeria's data. Third, the practical implications of this study, based on the causal findings, are relevant to financial products developers, financial institutions, and regulators through the recommendation of significant changes in policy and regulatory guidelines that can drive mobile money transformation in Nigeria.

This article is, therefore set out to examine the causal linkages between mobile money and the performance of selected banks in Nigeria. The study deployed the autoregressive distributed lag (ARDL) model and two proxy variables to measure bank performance i.e., profit before tax and total assets to investigate the hypotheses. The study is structured as follows. In the second section, the study reviewed conceptual, empirical and theoretical literature. Section three contains methodology, section four details out the analysis of the data, section five discusses the findings, section six presents the conclusion based on the results, and section seven reports implications and future research direction.

\section{LITERATURE REVIEW}

\section{Mobile Money and Banks' Financial Performance}

Mobile money is the use of mobile devices to conduct formal financial transactions without necessarily owning a formal bank account (Donovan, 2012; Shrier, Canale and Pentland, 2016). Mobile money is a viable option for extending financial services to disadvantaged groups, including the poor and rural dwellers. The simplicity of mobile phone channels makes it easily adaptable. Software applications, web browsers, unstructured supplementary service data (USSD), and short messaging service (SMS) are mobile phone channels via which financial transactions could be performed (Donovan, 2012). The portability of mobile phones and the ease of use make them an excellent tool for financial transactions. Mobile money could enhance financial inclusion by eliminating the difficulties associated with the opening of formal bank accounts. Yakub, Bello and Adenuga (2013) observed that mobile money could strengthen commerce, offer security to users, allow for microfinance, create ease of remittance, increase the income of rural dwellers, and create job and financial empowerment. Mobile money provides a range of services which include transfers, balance enquiries, withdrawals, making payments, deposits, receiving international remittances, making drafts and cell top-up (Bank, Ernst and Young, 2009; Klein and Mayer, 2011; Shrier et al., 2016). A good reason for considering mobile 
money as a tool for enhancing financial inclusion especially in Africa is that there exists a gap between the number of formal accounts and active mobile phone subscribers (Yakub, Bello and Adenuga, 2013). This assertion is supported by the (Enhancing Financial Innovation and Access [EFInA], 2018) report, which reveals that 39.7 percent of Nigeria's adult population owns formal bank accounts as against 68.9 percent who own mobile phones. While there is a limit to the geographical spread of banks, mobile services are ubiquitous. The ubiquity of mobile phone services means that mobile phones are more accessible when compared to standard banking services (Etim, 2014). The use of agents or merchants in opening mobile money accounts and for cash-in cash-out purposes (Donovan, 2012) makes mobile money a tool for job creation. On the other hand, Klein and Mayer (2011) opined that while mobile money enhances financial performance, it also raises concerns about regulation and competition. Similarly, Merritt (2011) suggested that while mobile money creates a convergence between the banking and telecommunication industries, it also throws up the challenge of establishing proper regulation particularly for the telecom industry that lacks the requisite expertise in rendering financial services.

Regarding mobile money and financial performance of banks, earlier studies have determined that once adopted on a massive scale, mobile money offers the improved financial inclusion and financial sector development. On the one hand, given the lack of access to quality financial services in developing economies, the poor rural households are willing to adopt and use mobile money for it provides an accessible, convenient, cheap, and secure way of transferring money, saving money, and making payments (e.g., Mago and Chitokwindo, 2014; Mbiti and Weil, 2011). Gustavi (2018) showed that mobile money helps to reduce the incompleteness of financial markets and increases the macroeconomic stability of the countries where mobile money is widespread, with benefits going mainly to rural, low-income households. Mobile money as a financial innovation indeed contributes to and is positively correlated to profitability in the banking sector, particularly that of commercial banks (Nyathira, 2012). Mobile money improved the commercial banks' financial performance in Kenya. The study revealed that there was a steady decline in the commercial banks' capital expenses management ratio as illustrated by the decrease in mean values from 0.32 in the year 2009 to 0.25 in the year 2013 (Kengere, 2014). Meanwhile, a serious debate on whether mobile money has contributed to the performance of the Nigerian banking sector subsists in the literature. The argument is that Nigeria's financial system is not effectively providing its development roles as such and is currently not in a position to fulfil its potential as a propeller of economic growth and development (Nkoro and Uko, 2013).

Figure 1 (see Appendix-I) clearly reveals that globally, a fresh 143 million registered consumers 


\section{Iheanachor \& Ozegbe}

were added to the mobile money market in 2018, with the aggregate number of accounts increasing to 866 million, which represent a 20 percent increase per annum (Global System for Mobile Association [GSMA], 2018)

In 2017, the Asian region accounted for the largest growth in mobile money operation, with over 90 million new accounts (GSMA, 2018). The highest year-over-year account growth rate was experienced in East Asia and Pacific with a growth rate of 38 percent, just as the region now holds 11 percent of global registered accounts (GSMA, 2018). In 13 African nations, about 33 percent of the adult population is active users of mobile money (GSMA, 2018), while activity rates in Sub-Saharan Africa remain stable at 36.8 percent, mostly unchanged from 2017, the region added over 17.5 million new active accounts in 2018 (GSMA, 2018).

Figure 2 shows that in 2016, approximately 98.7 percent of the Nigerian adult population were not registered and had never used mobile money services (EFInA, 2018). This figure marginally improved by 2 percent when the proportions that were not registered declined to 96.7 percent in 2018 (EFinA, 2018). The ratio of the population who had used mobile money but not anymore rose from 0.3 percent in 2016 to 0.7 per cent in 2018 (EFinA, 2018), but 1.1 percent of the population, used mobile money services, not registered as in the last quarter of 2018, while it was 0.2 percent at the end of 2016 . Further, an estimated ratio of 0.8 percent of the population was duly registered in 2016, while that figure significantly improved to 1.7 percent as of 2018 (EFinA, 2018).

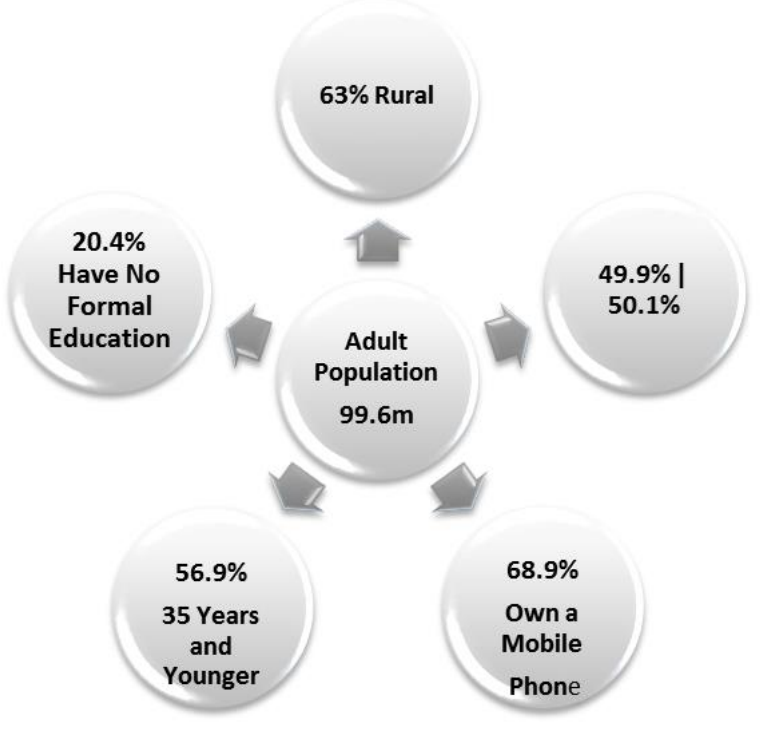

Source: Authors' Presentation

Figure 2. Demographic Profile of Nigeria's Adult Population 2018 


\section{Theoretical Framework}

This study is anchored on Teece et al.'s (1997) dynamic capability theory which explains how firms adapt to environmental dynamism by modifying their underlying resources and capabilities. Teece et al. (1997) initially defined dynamic capabilities as the ability to combine, reconfigure and build internal and external resources to address rapidly changing environments. Teece (2007) expounded this definition to opine that dynamic capabilities can be disaggregated into the capacity to (i) forecast opportunities and address threats (ii) exploit opportunities to drive performance (iii) maintain competitiveness through enhancing, combining, protecting, and when necessary, reconfiguring the business enterprises intangible and tangible resources. Tashman and Marano (2010) consider dynamic capabilities in the context of dynamic or emerging markets, highlighting that there are volatility and change in these markets that justify the development of dynamic capabilities to be competitive. By their nature, dynamic capabilities are suited to dynamic markets, being able to cater for changes through adapting current resources and routines (Teece, 2007). The fundamental principle behind them is continued competitiveness, as firms are not only competing in their ability to configure and exploit existing resources but also in their ability to renew and develop these resources (Prasad et al., 2017).

The capabilities and resources of mobile money enterprises may be internal or external (Pang, Lee and DeLone, 2014). Internal resources and capabilities may be tangible or intangible. The primary internal resources and capabilities used by mobile money enterprises include mobile phones, sim cards, vendors' relationship with customers, staff knowledge, financial capital, and location. However, their essential external resources include support services from commercial banks, education and support services from mobile service providers (Adaba, Ayoung and Abbott, 2019; Asamoah, Takieddine and Amedofu, 2020; Fiasorgbor and Caroline, 2017). The emergence of mobile money in Nigeria and the decision of the regulatory authority and other critical stakeholders in the Ecosystem to favor a bank-led model created an opportunity for banks to exploit. Nigerian banks seized their opportunity as critical stakeholders in the mobile money market to deploy tangible and intangible resources to leverage on the newly found opportunity to drive performance (David-West et al., 2019a). Moreover, the underlying objective of mobile money enterprises is to attain business growth, which eventually leads to development. To realize this, they integrate, build and reconfigure their internal and external capabilities based on their goals and strategies (Pang et al., 2014).

In the context of this article, mobile money is considered as essential parts of Nigerian banks' dynamic capabilities based on the model deployed in the country. In the same vein, the mutually exclusive relationship between mobile money enterprises and commercial banks in Nigeria based on 


\section{Iheanachor \& Ozegbe}

the bank-led model indicates that the banks are vital external dynamic capabilities of the mobile money enterprises. Therefore, mobile money enterprises and commercial banks in Nigeria separately combine their internal and external capabilities and resources to achieve their corporate objectives.

\section{Dynamic Capabilities and Firms' Performance}

Investigations on dynamic capabilities and firms' performance in terms of either the economic performance of the firm or changes in operational capabilities predominantly exists. However, the mechanisms through which they influence performance remain unclear. Some scholars posited a direct relationship between dynamic capabilities and performance. Following this view, several empirical studies report a direct relationship between what the authors conceptualize as dynamic capabilities and performance (Drnevich and Kriauciunas, 2011; Lin and Wu, 2014; Teece, 2014; Wilden et al., 2013). Concerning the performance indicators, there is considerable variation in what constitutes performance. Many studies focus on economic performance (Pervan, Curak and Kramaric, 2018; Roberson, Holmes and Perry, 2017; Yook, Choi and Suresh, 2018), whereas others consider technological performance, environmental performance, and cross-border market performance (Del Rosario, Sánchez-Medina and Díaz-Pichardo, 2019; Mikalef and Pateli, 2017; Pinho and Prange, 2016).

Firm performance has been the most critical issue for every firm, be it a profit or non-profit one. However, defining, conceptualizing, and measuring firm performance has not been an easy task (Soudani, 2012). Firm performance has been taught with many conflicting definitions, and it is not a new phenomenon to academics and industrialists (Mikalef and Pateli, 2017). Firm performance is a combination of productive assets made up of human, physical, and capital resources, for the significant reason of fulfilling vision or shared purposes (Afonina, 2015). It is also defined as the measurement of management's efficient and effective utilization of firm's resources for the attainment of its primary and secondary objectives (Mark and Nwaiwu, 2015).

Firm performance is the real output measured against the expected or intended output (Mapalala, West and Winston, 2018). It comprised of three areas i.e., a financial performance that made up of profit e.g., return on assets (ROA), return on investment (ROI); product market performance such as sales, and market share; and shareholders return such as total shareholder return (TSR), and economic value added (EVA). Firm performance involves the recurring activities to establish its goals, monitor projects towards the attainment of goals, and effect necessary adjustments to achieve these goals more effectively and efficiently (Mapalala et al., 2018).

From the literature, we observed that mobile money has a direct relationship with the performance 
of banks. However, it is unclear in literature both empirical and theoretical, whether mobile money has a causal long-run relationship with the performance of Nigerian banks in terms of their profit before tax and total assets. To close the empirical and theoretical gaps identified above the study proposes the following hypotheses.

\section{Mobile Money and Bank's Profit}

Mobile money greatly influences profit in commercial banks and to a great extent, the institutions' financial performance (Baganzi and Lau, 2017). In line with the underlying tenet of dynamic capabilities theory of the firm which underpins this study, commercial banks operating in a dynamic and highly competitive environment like the Nigerian banking industry must make use of mobile money to increase customer loyalty, increase the flow of funds from depositors and to investors with the result of increasing profitability and financial performance. To attract more customers, banks integrate resources and capabilities such as mobile money agents, good location, and relationship with customers and excellent support services from mobile network providers that accentuate profit (Teece, 2012).

According to Masocha and Dzomonda (2018), and Talom and Tengeh (2020), the rapid diffusion of mobile money operations is seen as a potentially critical tool for accelerating banks' profits. This indicates that the rapid adoption of mobile money services is seen as a way to improve the financial functionality and hence the overall performance of commercial banks. For Talom and Tengeh (2020), the performance of commercial banks can be measured by evaluating the volume of profit before and after-tax, which remains one of the main determinants of firms' performance (Kamukama and Tumwine, 2012; Kisaka et al., 2015). Based on the literature presented, the following hypothesis is proposed:

$\mathrm{H}_{01}$ : There is no forward-backward causal linkage between mobile money and profits.

\section{Mobile Money and Bank's Total Assets}

In the literature, the relationship and mechanism through which mobile money influences the total assets of banks as performance indicator remain scanty. However, some scholars posited a direct relationship between dynamic capabilities of firms and their overall performance which can be determined in terms of financial indicators such as total assets, profit, sales growth, market shares, and non-financial indicators such as knowledge transfer, research and development and organization's culture (Robin, Salim and Bloch,2018).

This study will test whether the lag of total assets and mobile money positively influences the 


\section{Iheanachor \& Ozegbe}

current level of total assets of the selected banks or otherwise. Secondly, the study will test if the previous period's total assets are a significant determinant of current assets and also determine if mobile money significantly contributes to the current asset base of financial institutions investigated.

Focus on banks' assets in their statements of financial position at the end of the year reflects the effect that mobile money has on the banks' operations and transactions. Banks have evolved over time and thus, the need to increase convenience, efficiency, transactional optimization and the need for customer loyalty in order to develop a competitive edge. These dynamic capabilities have increased the speed, simplicity with which transaction is done and thus increased the total asset base, returns on investment and profitability of the banks.

$\mathrm{H}_{02}$ : There is no causation between mobile money and total assets.

\section{METHODOLOGY}

\section{Sample and Procedure}

The population of this study consists of 22 commercial banks in Nigeria. A sample of 4 of these banks was drawn for analysis. The four sampled banks were selected because they are the largest in the country and control over 70 percent of mobile money activities in terms of the volume and value of transactions in the country (Nigerian Inter-Bank Settlement System [NIBSS], 2018). Therefore, the analysis of these four banks would be adequate to make our inference on the phenomenon of interest. These banks were selected using a purposive sampling technique. Quarterly data for the sampled banks spans the period of the first quarter of 2014 to the fourth quarter in 2018. In addition to data availability, this era coincides with the advent of mobile money adoption in the country. The explanatory variable i.e., mobile money (MMO) was sourced from (NIBSS, 2018), other data were sourced from the annual financial reports of the (Nigerian Stock Exchange [NSE], 2018) for the selected banks. The data were eventually paneled to capture the entire sampled banks in the analysis.

\section{Model Specification}

This study employed the modern autoregressive distributed lag (ARDL) model and Wald causality techniques to respectively ascertain the relationship between the explained and explanatory variables and the direction of causality, if any, exists between the variables. The ARDL technique was used to determine the short-run and long-run relationship simultaneously without the problem of nonstationarity (Alih et al., 2018). The study employed the bounds test (Pesaran, Shin and Smith, 1999) to determine whether a long-run relationship subsists. 
These methods of analysis are a sharp departure from previous studies (David-West et al., 2019b; Lepoutre and Oguntoye, 2018) that have investigated mobile money in the past but aligned with the work of Alih et al., (2018). The strength of these techniques added to the robustness and policy implications of this study.

The ARDL is the least-squares regression that contains lags of the explained and explanatory variables. ARDL usually denoted with the notation $\operatorname{ARDL}(p, q 1 \cdots)$, where $p$ is the number of lags of the explained variable, $q 1$ is the number of lags of the first explanatory variable, and $q k$ is the number of lags of the $k^{\text {th }}$ explanatory variable.

An ARDL model could take a general form:

$$
y_{t}=\alpha+\sum_{i=1}^{p} \gamma_{i} y_{t-i}+\sum_{j=1}^{k} \sum_{i=0}^{q j} X_{j, t-1}^{I} \beta_{j, t}+\varepsilon_{i}
$$

Following equation 1 above, are the models' specification for this study. Model One:

$$
\operatorname{LnPBT}_{t}=\alpha_{0}+\alpha_{1} \operatorname{LnPBT}_{t-1}+\alpha_{2} \operatorname{LnMMO}_{t-1}+\varepsilon_{t}
$$

Model Two

$$
\operatorname{LnTA}_{t}=\alpha_{0}+\alpha_{1} \operatorname{LnTA}_{t-1}+\alpha_{2} \operatorname{LnMMO} O_{t-1}+\varepsilon_{t}
$$

From model 2 and 3 above, " $L n$ " is the natural logarithm of the variables; $L n P B T_{t-1}$ is profit before tax lagged by one period, $\mathrm{LnMM}_{\mathrm{t}-1}$ represents the lag of mobile money lagged by one period, LnTA $\mathrm{t}_{-1}$ stands for total assets lagged by one period while $\varepsilon_{t}$ is the stochastic error term. The variables on the right-hand side of the models are the dynamic regressors.

\section{Data Analysis}

In this section, the study employed pre-estimation tests, estimation, and post-estimation analyses. The pre-estimation tests include the summary statistics and the stationarity test based on the Augmented Dickey-Fuller (ADF). The $f$-bounds test and ARDL estimation conducted in the estimation process, and the post estimation tests include the Wald causality test amongst others.

\section{-Summary Statistics}

The result of the descriptive statistics is presented in Table 1. The summary statistics table revealed that for all variables, the mean is higher than the standard deviation. The result shows that the variables are not widely dispersed. The skewness result showed that all the variables are positively 


\section{Iheanachor \& Ozegbe}

\begin{tabular}{lccc}
\hline & MMO & PBT & TA \\
\hline Mean & $8.17 \mathrm{E}+11$ & 108552.7 & 3143685. \\
Median & $7.56 \mathrm{E}+11$ & 111562.5 & 3201868. \\
Maximum & $1.80 \mathrm{E}+12$ & 231685.0 & 5955710. \\
Minimum & $1.46 \mathrm{E}+10$ & 14548.00 & 1008451. \\
Std. Dev. & $6.25 \mathrm{E}+11$ & 70776.12 & 1471189. \\
Skewness & 0.345152 & 0.159774 & 0.199895 \\
Kurtosis & 2.004633 & 1.914667 & 2.188435 \\
Jarque-Bera & 1.222730 & 1.066716 & 0.682058 \\
Probability & 0.542610 & 0.586632 & 0.711038 \\
Sum & $1.63 \mathrm{E}+13$ & 2171054. & 62873704 \\
Sum Sq. Dev. & $7.42 \mathrm{E}+24$ & $9.52 \mathrm{E}+10$ & $4.11 \mathrm{E}+13$ \\
& & & \\
Observations & 80 & 80 & 80 \\
\hline
\end{tabular}

Source: Authors' Computation

Table 1. Descriptive Statistics

skewed between the range of 0.156 and 0.345 . The positive skewness values indicated that the variables are skewed to the right, that is, have a long tail to the right. However, because the skewness values are not significantly larger than zero, we can conclude that the variables tend towards asymmetric distribution. Also, the kurtosis values are lesser than 3 . The kurtosis implied that variables are platykurtically distributed, that is, having a shorter tail than the normal distribution. The JarqueBera statistic measures the normality of the data series. With $p$-values greater than 0.05 , we conclude that the series is approximately normally distributed. However, to ensure that the series utilized did not produce a spurious outcome, we decided to establish further the stationarity properties of the variables using the ADF unit root test.

\section{-Unit Root Test}

The ADF test employed in the stationarity features of the series under the Akaike Information criterion with both trends and intercepts. The result, as presented in Table 2, indicates that the variables are integrated in different orders. While LnMMO integrated at Nature, LnPBT and LnTA are stationary in their respective first differences. In summary, at 5 percent significant level, the absolute values of LnMMO ADF statistic is more significant than its corresponding critical value at the level. Thus, the variable is stationary at level. Although the other variables were not stationary at level, after the first difference, both became stationary as shown in their probability values and their corresponding ADF statistics being higher than their critical values in absolute term.

Since the variables integrated into different orders zero and one, there is a need to determine if the 
variables are cointegrated. The result of the unit root test supports the adoption of ARDL estimation technique, and the associated cointegration test is the $f$-bounds test.

\begin{tabular}{ccccc}
\hline Variable & ADF statistic & $\boldsymbol{t}$-critical @ 5\% & $\boldsymbol{p}$-value & Order of Integration \\
\hline LnMMO & -4.232207 & -3.710482 & 0.0199 & $\mathrm{I}(0)$ \\
LnPBT & -4.160832 & -3.690814 & 0.0214 & $\mathrm{I}(1)$ \\
LnTA & -4.675793 & -3.040391 & 0.0019 & $\mathrm{I}(1)$ \\
\hline \multicolumn{2}{l}{ Source: Authors' Computation using Eviews 10 }
\end{tabular}

Table 2. Unit Root Test (ADF)

\section{-Cointegration Test (Bounds Test)}

The bounds test results are presented in Table 3 for model one and model two. The result of the bounds test for model one indicated $f$-statistic value of 0.780796 , which is lesser than the upper and lower bounds at all levels of significance. The result implied the acceptance of the null hypothesis that there is no long-run relationship between banks' profit before tax and mobile money. This finding, therefore, conditioned the authors to only the short-run analysis of the relationship between banks' performance and mobile money in Nigeria.

Similarly, the bounds test for model two is also presented in Table 3. The result indicates that the $f$ bounds statistic value of 1.754923 which is lesser than both upper and lower bounds at all levels of significance suggested the absence of a long-run relationship between banks' total assets and mobile money in Nigeria. Therefore, only the short-run nexus would be estimated.

\begin{tabular}{ccccc}
\hline Test Statistic & Value & Sig. & $\mathbf{I}(\mathbf{0})$ & I(1) \\
\hline \multirow{2}{*}{-statistic } & 0.780796 & $10 \%$ & Asymptotic: $\mathrm{n}=1000$ & \\
$\mathrm{~K}$ & 1 & $5 \%$ & 3.02 & 3.51 \\
& & $2.5 \%$ & 3.62 & 4.16 \\
& & $1 \%$ & 4.18 & 4.79 \\
Actual Sample Size & 19 & $10 \%$ & 4.94 & 5.58 \\
& & $5 \%$ & Finite Sample: $\mathrm{n}=35$ & \\
& & $1 \%$ & 3.223 & 3.757 \\
& & & 3.957 & 4.53 \\
& & $10 \%$ & Finite Sample: $\mathrm{n}=30$ & 6.48 \\
& & $5 \%$ & 3.303 & 3.797 \\
& & $1 \%$ & 4.09 & 4.663 \\
& & & 6.027 & 6.76 \\
\hline Source: Authors' Computation using Eviews 10 & & &
\end{tabular}

Table 3.f-Bounds Test Null Hypothesis: No Levels Relationship

To see short-run ADRL model results and the Wald causality test, please see Table 4 (Appendix-II), 


\section{Iheanachor \& Ozegbe}

Table 5 (Appendix-III), Table 6 (Appendix-IV), and Table 7 (Appendix-V).

\section{DISCUSSION}

The result of ARDL short-run estimates for model one is shown in Table 4. The model focused on the dynamic relationship between mobile money and banks' profit before tax in Nigeria using four selected banks. The autoregressive distributed lag model result indicates that the coefficients of the explanatory variables are in line with theory. That is, the previous year's profit performance of the banks positively and significantly influences profit level in the current period, but mobile money variable has a negative coefficient which implied that it somewhat hampers banks profitability performance indicator. The inverse relationship between mobile money and banks profitability can be rationalized using the dynamic capability theory (Teece et al., 1997).

Statistically, the previous year's level of profit significantly influences the current level of profits of the banks. The specific impact is such that for every 1 percent rise/fall in the previous period's profit, the current profit level exchanges to follow at the rate of 0.93 percent. However, for mobile money, as it rises/falls by 1 percent, banks' performance via profitability falls/rises by 0.01 percent, but this is statistically insignificant.

The robustness of the model was tested using the coefficient of determination and the $p$-values of $f$-statistic. The adjusted coefficient of determination of 85 percent implied a high predictive power of the model. It further suggested that changes in banks' performance accounted for by previous period performance and mobile money to the tune of 85 percent while only 15 percent is accounted for by other factors not captured by the model. The $f$-statistic result corroborated the $\mathrm{R}^{2}$ result of high goodness of fit; this is evident in the 0.0000 probability value of the $f$-statistic, evidently, the overall model is statistically significant.

From Table 3, the bounds test indicated that the $f$-statistic value falls below the upper and lower bounds. The implication of that is the absence of a long-run relationship between mobile money and banks' performance metrics of profit before tax. Thus, the study rejected the alternative hypothesis and accepted the null hypothesis, which states that there is no long-run relationship between mobile money and banks' profit before tax.

In model two, the study estimated the short-run influence of mobile money on total assets of selected banks. The result, as presented in Table 5 revealed interesting empirical findings. First, both the lag of total assets and mobile money positively influenced the current level of total assets of the selected banks. Second, while previous period's total assets are a significant determinant of current assets, mobile money does not significantly contribute to the current asset base of the financial institu- 
tions investigated. Third, mobile money variable and the lag of total assets by one period jointly account for over 79 percent of the systematic variations in banks' performance, while less than 20 percent are unaccounted for in the model. The robustness of the model is further supported by the $p-$ value of $f$-statistic, which is approximately 0.0000 . Also, the Durbin-Watson statistic of 2.2 signified the absence of serial correlation problem in the model. Thus, the estimates are suitable for prediction and policy formulation.

From Table 5, the bounds test showed that the $f$-statistic value is lesser than both the upper and lower bounds at all significance levels. The result implied the absence of a long-run relationship between mobile money and banks' performance metrics of total assets. Thus, based on the empirical evidence, the study accepted the null hypothesis that there is no long-run relationship between mobile money and banks' performance and rejected the alternative hypothesis. Thus, mobile money and banks performance are not related in the long-run; it is only a short run affair.

\section{-Causality Test (Wald Test)}

The crux of this study was to determine whether a bi-directional causal relationship exists between mobile money and profitability on one hand, and mobile money and total assets of banks on the other hand as indicated in Table 6.

$\mathrm{H}_{01}$ : There is no forward-backward causal linkage between mobile money and profits

$\mathrm{H}_{02}$ : There is no causation between mobile money and total assets

To empirically test study hypotheses, the study employed the Wald causality test (see results in Table 6 and 7 ), for model one and model two, respectively.

To test for $\mathrm{H}_{01}$ i.e., there is no forward-backward causal linkage between mobile money and profits, the value of Chi-square statistic was 104.46 with a corresponding probability value of 0.0000 and the $f$-statistic value of 52.23 with $p$-value of 0.0000 implied the existence of a bi-directional causal relationship between mobile money and banks' profits. This indicates that rising profit promotes the adoption of mobile money and the adoption of mobile money feedback into the profit of the bank. Thus, the study rejected the null hypothesis which stated that there is no forward-backward causal linkage between mobile money and profit, and accepted the alternative hypothesis that a bi-directional causal linkage exists between mobile money and profits of the selected banks.

Further, the result of the Wald causality test also indicated an $f$-statistic value of $52.43(0.0000)$ and Chi-square value of $52.43(0.0000)$. These figures evidently supported the refutation of the $\mathrm{H}_{02}$ that there is no causation between mobile money and banks total assets in Nigeria. Again, the study is provided with empirical strength to accept the opposing hypothesis of the existence of bi-directional 


\section{Iheanachor \& Ozegbe}

causal linkages between mobile money and banks total assets. This also implied that as banks increasingly adopt mobile money services, their asset base is enhanced, while rising assets base further feedback to support wider adoption of mobile money services. From the forgoing, our findings hold tremendous implications for theory, methods, practice, and policy.

From the above discussion of findings, our empirical outcomes lend supports and justification for the dynamic capability theory expounded by Teece et al., (1997) which asserted the use of capabilities and resources such as mobile money services to drive profitability and grow asset base. Thus, Nigerian banks have continued to explore the avenue of mobile money to improve their profitability and assets bases. This assertion is consistent with the tenets of the dynamic capability theory which undergirds this study. Evidence from this study suggests that mobile money may have some positive effects on the overall performance of the Nigerian banking industry. However, such impacts do not have any direct long-term relationship with the performance of banks in terms of improved volume of profit and the assets base. The lack of long-run impact of mobile money on banks' performance metrics is an indicator of the under-developed nature, lack of trust and poor patronage of traditional mobile money channels by Nigerians. The reports of this study corroborate earlier evidence published by (Robin et al., 2018). From the preceding, the study draws conclusion and policy implications that are relevant in theory and practice.

\section{CONCLUSION}

This study investigated the causal linkage between mobile money and performance of banks in the Nigerian financial industry. Although the volume and value of transaction of mobile money maintained a steady rise and a positive outlook within the period under review, however, empirical evidence from our analyses reveals that the previous year's profit performance of the banks positively and significantly influences profit level in the current period. However, mobile money variable has a negative coefficient which implied that it slightly hampers than promotes banks' profitability performance.

The implication of that is the absence of a long-run relationship between mobile money and banks' performance metrics of profit before tax. Again, both the lag of total assets and mobile money positively influenced the current level of total assets of the selected banks. Moreover, while the previous period's total assets are a significant determinant of current assets; mobile money does not significantly contribute to the current assets base of the financial institutions investigated.

\section{IMPLICATIONS}


This study upholds Teece's dynamic capability theory in different dimensions. Firstly, it indicates that in an attempt by banks to continually improve their performance which is measured by profit before tax and total assets in this study. Banks expected to exploit their opportunity as critical stakeholders in the mobile money market to deploy tangible and intangible resources to drive performance. Evidence from this study suggests that mobile money may have some positive effects on the overall performance of the Nigerian banking industry. However, such impacts do not have any direct long-term relationship with the performance of banks in terms of improved volume of profit before tax and the total assets of the investigated banks. This position is consistent with the study conducted by Robin et al. (2018). But, empirical evidence indicates a lead-lag relationship between mobile money and banks' performance parameters employed - profit and assets. The position of our report is based on the adoption of a modern econometric method. The ARDL method is modern in approach, it is scientific and simultaneously estimates the long-run and short-run impacts. Thus, the modernity of our method justifies the bi-directional linkages found in our study and the implication is a swift departure from existing studies that adopted less scientific methods of analysis.

Therefore, mobile money services in Nigeria have contributed favorably to the financial growth of the banking industry. From the findings, it is evident that mobile money causes an improvement in the profit and assets base of commercial banks operating in Nigeria. Therefore, the policy implication is that the management of the commercial banks should consolidate their investment in mobile money and other dynamic opportunities within the banking industry as means of improving overall financial performance. The study also revealed causal relationship between mobile money and banks' performance metrics of total assets. As such, the study suggests that the management of the commercial banks should strive to achieve an optimal capital structure to enhance internal and external capabilities/ resources that can boost financial performance.

\section{LIMITATIONS AND FUTURE DIRECTIONS}

The key limitation of this study is its country-specific approach. Also, the study is limited in the number of commercial banks considered in its analysis. Studies interested in the mobile money and banks' performance research space should adopt a panel analysis approach with selected countries from Asian and the African continents where mobile money operates on a large scale. Such analysis would produce findings that could aid generalization on the true impact and causal nexus between both constructs. Further, a future study could depart from the ARDL approach by considering a dynamic balanced regression analysis with both fixed and random effects. The Hausman's test is suggested for selection of the appropriate effects. 


\section{Iheanachor \& Ozegbe}

\section{REFERENCES}

Adaba, G. B., Ayoung, D. A. \& Abbott, P. (2019). Exploring the contribution of mobile money to well-being from a capability perspective. The Electronic Journal of Information Systems in Developing Countries, 85(4): 1-19. https://doi.org/10.1002/isd2.12079

Afonina, A. (2015). Strategic management tools and techniques and organizational performance: Findings from the Czech Republic. Journal of Competitiveness, 7(3), 19-36.

Alih, P. M., Sarmidi, T., Shaari, A. H. \& Said, F. F. (2018). Investigating the relationship between financial innovation and money demand in Malaysia: An ARDL approach to Cointegration. International Journal of Accounting, 3(15): 66-85.

Asamoah, D., Takieddine, S., \& Amedofu, M. (2020). Examining the effect of mobile money transfer (MMT) capabilities on business growth and development impact. Information Technology for Development, 26(1): 146-161. https://doi.org/10.1080/02681102.2019.1599798

Baganzi, R. \& Lau, A. K. (2017). Examining trust and risk in mobile money acceptance in Uganda. Sustainability, 9(12): 2233.

Bank, D., Ernst \& Young (2009). Working capital management: A survey of Nordic companies. Copenhagen, Denmark: Danske Bank A/S \& Ernst \& Young.

Chiu, C. Y., Chen, S., \& Chen, C. L. (2017). An integrated perspective of TOE framework and innovation diffusion in broadband mobile applications adoption by enterprises. International Journal of Management, Economics and Social Sciences, 6(1): 14-39.

David-West, O., Aluko, T. \& Adetunji, O. (2019). Mobile money: A panacea for financial exclusion in emerging markets. Journal of Banking, 8(1): 27-55.

David-West, O., Iheanachor, N. \& Umukoro, I. O. (2019). Mobile money as a frugal innovation for the bottom of the pyramidCases of selected African countries. Africa Journal of Management, 5(3): 274-302.

Del Rosario Reyes-Santiago, M., Sánchez-Medina, P. S. \& Díaz-Pichardo, R. (2019). The influence of environmental dynamic capabilities on organizational and environmental performance of hotels: Evidence from Mexico. Journal of Cleaner Production, 227, 414-423

Donovan, K. P. (2012). Mobile money, more freedom? The impact of M-PESA's network power on development as freedom. International Journal of Communication, 6(23): 2647- 2669

Drnevich, P. L. \& Kriauciunas, A. P. (2011). Clarifying the conditions and limits of the contributions of ordinary and dynamic capabilities to relative firm performance. Strategic Management Journal, 32(3): 254-279. https://doi.org/10.1002/smj.882

Enhancing Financial Innovation \& Access [EFInA]. (2018). Key findings: EFInA access to financial services in Nigeria: 2018 survey. Accessed from: www.efina.org.ng.

Etim, A. S. (2014). Mobile banking and mobile money adoption for financial inclusion. Research in Business and Economics Journal, 9(1): 441-462.

Erdem, E. \& Tugcu, C. T. (2012). Higher education and unemployment: A cointegration and causality analysis of the case of Turkey. European Journal of Education, 47(2): 299-309.

https://doi.org/10.1111/j.1465-3435.2012.01526.x

Fiasorgbor, D. A. F. \& Caroline, T. (2017). Mobile money use in Ghana: An assessment of its relevance in the financial inclusion of rural communities. Advances in Social Sciences Research Journal, 4(7): 18-37.

Gosavi, A. (2018). Can mobile money help firms mitigate the problem of access to finance in Eastern sub-Saharan Africa? Journal of African https://www.tandfonline.com/doi/full/10.1080/15228916.2017.1396791

Intelligence, G. S. M. A. (2018). The mobile economy 2018. www.gsma.com

Islam, A., Muzi, S. \& Meza, J. L. R. (2018). Does mobile money use increase firms' investment? Evidence from Enterprise Surveys in Kenya, Uganda, and Tanzania. Small Business Economics, 51(3): 687-708.

Kamukama, N. \& Tumwine, S. (2012). Mobile money services: a liquidity threat to Uganda's commercial banks. African Journal of Accounting, Economics, Finance and Banking Research, 8(8): 33-46.

Kengere, D. M. (2014). The effects of agency banking on the non-funded income of commercial banks in Kenya. Doctoral dissertation, University of Nairobi.

Kisaka, S. E., Ndi, G. M., Muriki, M. \& Muio, A. K. (2015). The relationship between mobile banking deepening and financial performance of commercial banks in Kenya. Research Journal of Finance and Accounting, 6(10): 156-172.

Klein, M. \& Mayer, C. (2011). Mobile banking and financial inclusion: The regulatory lessons. The World Bank.

Lepoutre, J. \& Oguntoye, A. (2018). The (non-) emergence of mobile money systems in Sub-Saharan Africa: A comparative multilevel perspective of Kenya and Nigeria. Technological Forecasting and Social Change, 131, 262-275.

Lin, Y. \& Wu, L. Y. (2014). Exploring the role of dynamic capabilities in firm performance under the resource-based view framework. Journal of Business Research, 67(3): 407-413. https://doi.org/10.1016/j.jbusres.2012.12.019

Mago, S. \& Chitokwindo, S. (2014). The impact of mobile banking on financial inclusion in Zimbabwe: A case for Masvingo Province. Mediterranean Journal of Social Sciences, 5(9): 221-230.

Mapalala, M. J., West, G. R. \& Winston, B. (2018). Examining the relationship between entrepreneurial orientation and organizational performance: The moderating role of organizational learning. International Leadership Journal, 10(3): 4-18.

Mark, J. \& Nwaiwu, J. N. (2015). Impact of political environment on business performance of multinational companies in Nigeria. African Research Review, 9(3): 1-10. https://doi.org/10.4314/afrrev.v9i3.1

Mbiti, I. \& Weil, D. (2011). Mobile Banking: The Impact of M-Pesa in Kenya. Working Paper 17129, 1050 Massachusetts Avenue. Cambridge, MA. 
Merritt, C. (2011). Mobile money transfer services: the next phase in the evolution of person-to-person payments. Journal of Payments Strategy and Systems, 5(2): 143-160.

Mikalef, P. \& Pateli, A. (2017). Information technology-enabled dynamic capabilities and their indirect effect on competitive performance: Findings from PLS-SEM and fsQCA. Journal of Business Research, 70, 1-16.

Masocha, R. \& Dzomonda, O. (2018). Adoption of mobile money services and the performance of small and medium enterprises in Zimbabwe. Academy of Accounting and Financial Studies Journal, 22(3): 1-11.

Munyegera, G. K. \& Matsumoto, T. (2016). Mobile money, remittances, and household welfare: panel evidence from rural Uganda. World Development, 79, 127-137. https://doi.org/10.1016/j.worlddev.2015.11.006.

Nigerian Inter-Bank Settlement System. (2018) Interbank instant payments https://nibss-plc.com.ng/wpcontent/uploads/2019/02/InstantPayments2018-New.pdf

Nigerian Stock Exchange. (2018). NSE 2017/2018 fact book. www.nse.com

Nkoro, E. \& Uko, A. K. (2013). Financial sector development-economic growth Nexus: Empirical evidence from Nigeria. American International Journal of Contemporary Research, 3(2), 87-94.

Nyathira, C. N. (2012). Financial innovation and its effect on financial performance of commercial banks in Kenya. Doctoral dissertation.

Okeke, T. C. \& Eze, G. A. (2018). Exploring mobile money adoption among the informal sector in Anambra State-Nigeria. International Journal of Development and Sustainability, 7(12): 2927-2942.

Okello C. B. G., Ntayi, J. M., Munene, J. C. \& Malinga, C. A. (2018). Mobile money and financial inclusion in sub-Saharan Africa: the moderating role of social networks. Journal of African Business, 19(3): 361-384. https://doi.org/10.1080/15228916.2017.1416214

Pang, M. S., Lee, G. \& DeLone, W. H. (2014). IT resources, organizational capabilities, and value creation in public-sector organizations: A public-value management perspective. Journal of Information Technology, 29(3): $187-205$. https://doi.org/10.1057/jit.2014.2

Pelletier, A. G., Khavul, S. \& Estrin, S. (2016). Mobile money around the world: International business models, institutional voids, and spillovers. Academy of Management Proceedings, 1, 17067. https://doi.org/10.5465/ambpp.2016.17067

Pervan, M., Curak, M. \& Pavic Kramaric, T. (2018). The influence of industry characteristics and dynamic capabilities on firms' profitability. International Journal of Financial Studies, 6(1): 4. https://doi.org/10.3390/ijfs6010004.

Pesaran, M. H., Shin, Y. \& Smith, R. P. (1999). Pooled mean group estimation of dynamic heterogeneous panels. Journal of the American Statistical Association, 94(446): 621-634.

Pinho, J. C. \& Prange, C. (2016). The effect of social networks and dynamic internationalization capabilities on international performance. Journal of World Business, 51(3): 391-403.

Prasad, S., Jaffe, J., Bhattacharyya, K., Tata, J. \& Marshall, D. (2017). Value supply chains at the base of the pyramid: Studies of past and present textile networks. Journal of Humanitarian Logistics and Supply Chain Management. 2(2): 142-161.

Roberson, Q., Holmes IV, O. \& Perry, J. L. (2017). Transforming research on diversity and firm performance: A dynamic capabilities perspective. Academy of Management Annals, 11(1): 189-216. https://doi.org/10.5465/annals.2014.0019

Robin, I., Salim, R. \& Bloch, H. (2018). Financial performance of commercial banks in the post-reform era: Further evidence from Bangladesh. Economic Analysis and Policy, 58, 43-54

Saal, M., Starnes, S. \& Rehermann, T. (2017). Digital financial services. Challenges and opportunities for emerging market banks. EM Compass; no. 42. Washington, D.C.: World Bank Group. http://documents.worldbank.org/curated/en/750421502949470

Shrier, D., Canale, G. \& Pentland, A. (2016). Mobile money \& payments: Technology trends. Massachusetts Inst. Technol.

Soudani, S. N. (2012). The usefulness of an accounting information system for effective organizational performance. International Journal of Economics and Finance, 4(5): 136-145.

Sunde, T. (2017). Foreign direct investment, exports and economic growth: ADRL and causality analysis for South Africa. Research in International Business and Finance, 41, 434-444.

Talom, F. S. G. \& Tengeh, R. K. (2020). The impact of mobile money on the financial performance of the SMEs in Douala, Cameroon. Sustainability, 12(1): 183.

Tashman, P. \& Marano, V. (2010). Peace through commerce, dynamic capabilities and base of the pyramid business strategies. Journal of Business Ethics, 89, 495-514.

Teece, D. J. (2007). Explicating dynamic capabilities: the nature and micro-foundations of (sustainable) enterprise performance. Strategic Management Journal, 28(13), 1319-1350.

Teece, D. J. (2014). The foundations of enterprise performance: Dynamic and ordinary capabilities in an (economic) theory of firms. Academy of Management Perspectives, 28(4): 328-352.

Teece, D. J., Pisano, G. \& Shuen, A. (1997). Dynamic capabilities and strategic management. Strategic Management Journal, 18(7): 509-533.

Vincent, O. \& Evans, O. (2019). Can cryptocurrency, mobile phones, and internet herald sustainable financial sector development in emerging markets? Journal of Transnational Management, 24(3): $259-279$. https://doi.org/10.1080/15475778.2019.1633170

Wilden, R., Gudergan, S. P., Nielsen, B. B. \& Lings, I. (2013). Dynamic capabilities and performance: strategy, structure and environment. Long Range Planning, 46(1-2): 72-96.

Yakub, J. O. Bello, H. T., \& Adenuga, I. A. (2013). Mobile money services in Nigeria: An inquiry of existing models. International Journal of Economics and Management Sciences, 2(9): 94-105.

Yook, K. H., Choi, J. H. \& Suresh, N. C. (2018). Linking green purchasing capabilities to environmental and economic performance: The moderating role of firm size. Journal of Purchasing and Supply Management, 24(4): 326-337. 


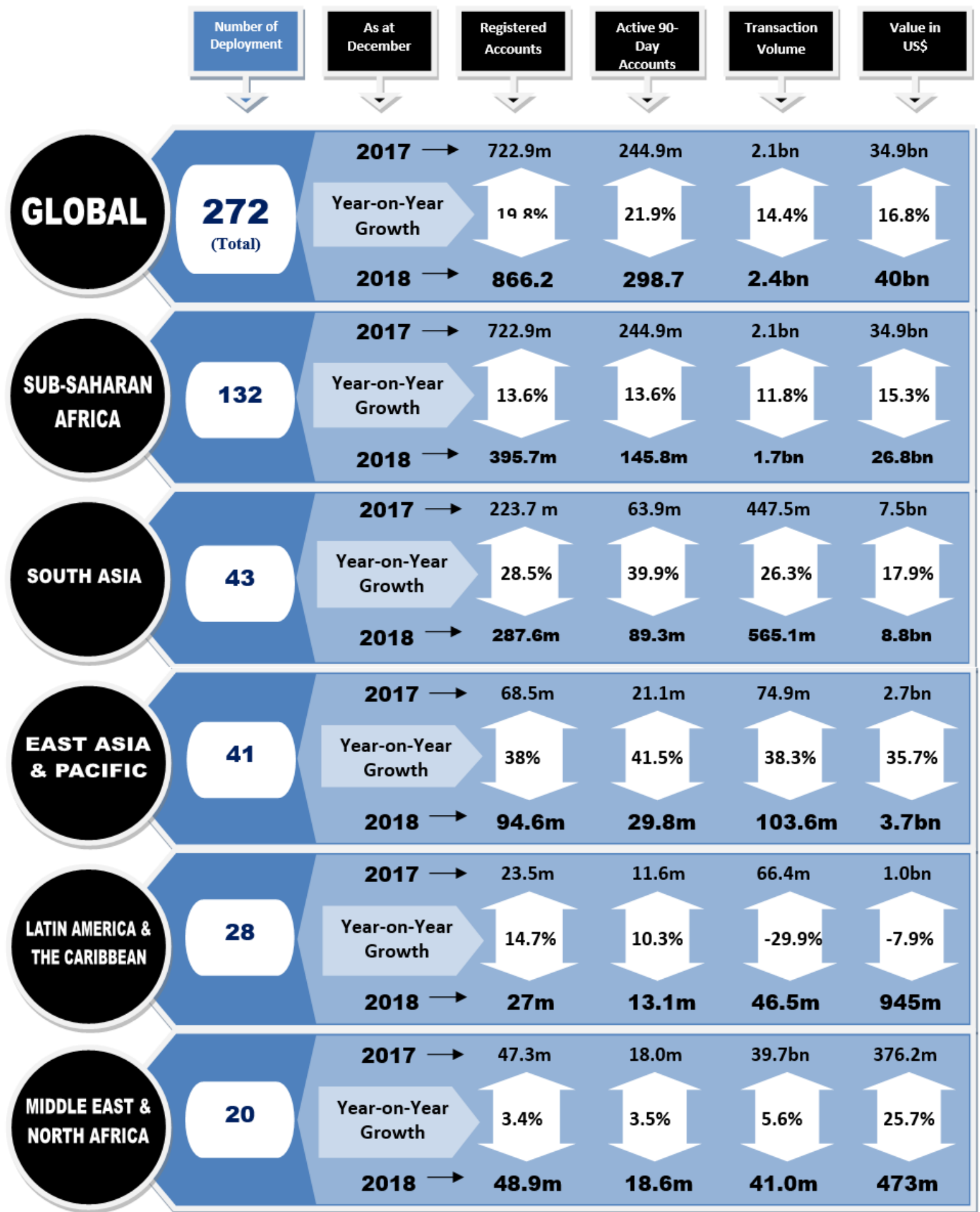

Source: GSMA, 2018

Table 1. Mobile Money Regional Growth 2018 


\begin{tabular}{lllll}
\hline Variable & Coefficient & Std. Error & $\boldsymbol{t}$-Statistic & Prob.* \\
\hline LNPBT(-1) & 0.934338 & 0.091417 & 10.22056 & 0.0000 \\
LNMMO & -0.011434 & 0.053282 & -0.214590 & 0.8328 \\
C & 1.155181 & 1.739134 & 0.664228 & 0.5160 \\
R-squared & 0.867181 & Mean dependent var & 11.32468 \\
Adjusted R-squared & 0.850579 & S.D. dependent var & 0.946989 \\
S.E. of regression & 0.366059 & Akaike info criterion & 0.971895 \\
Sum squared resid & 2.143987 & Schwarz criterion & 1.121016 \\
Log likelihood & -6.232998 & Hannan-Quinn criter. & 0.997132 \\
$f$-statistic & 52.23246 & Durbin-Watson stat & 1.435910 \\
Prob(f-statistic) & 0.000000 & & \\
\hline
\end{tabular}

Source: Authors' Computation

Note: $p$-values and any subsequent tests do not account for model Selection.

Table 4. ARDL Result for Model One in the Short-Run 


\begin{tabular}{lllll}
\hline Variable & Coefficient & Std. Error & $\boldsymbol{t}$-Statistic & Prob.* \\
\hline LNTA(-1) & 0.846389 & 0.107441 & 7.877713 & 0.0000 \\
LNMMO & 0.022349 & 0.035087 & 0.636978 & 0.5331 \\
C & 1.765790 & 1.829843 & 0.964995 & 0.3489 \\
R-squared & 0.796780 & Mean dependent var & 14.88860 \\
Adjusted R-squared & 0.771378 & S.D. dependent var & 0.504200 \\
S.E. of regression & 0.241081 & Akaike info criterion & 0.136568 \\
Sum squared resid & 0.929918 & Schwarz criterion & 0.285690 \\
Log likelihood & 1.702600 & Hannan-Quinn criter. & 0.161806 \\
$f$-statistic & 31.36628 & Durbin-Watson stat & 2.282374 \\
Prob $(f$-statistic $)$ & 0.000003 & & \\
\hline
\end{tabular}

Source: Authors' Computation

Note: $p$-values and any subsequent tests do not account for model Selection.

Table 5. ARDL Result for Model Two in the Short-Run 


\begin{tabular}{llll}
\hline Test Statistic & Value & $\boldsymbol{d} \boldsymbol{f}$ & Probability \\
\hline f-statistic & 52.23246 & $(2,16)$ & 0.0000 \\
Chi-square & 104.4649 & 2 & 0.0000 \\
\hline
\end{tabular}

Source: Authors' Computation

Table 6. Wald Causality Test for Model One 
Iheanachor \& Ozegbe

Appendix-V

\begin{tabular}{llll}
\hline Test Statistic & Value & $d f$ & Probability \\
\hline$t$-statistic & 7.241068 & 16 & 0.0000 \\
$f$-statistic & 52.43306 & $(1,16)$ & 0.0000 \\
Chi-square & 52.43306 & 1 & 0.0000 \\
Null Hypothesis: $\mathrm{C}(1)=\mathrm{C}(2)$ & & \\
Null Hypothesis & Summary: & & \\
Normalized Restriction $(=0)$ & Value & Std. Err. \\
C(1) - C(2) & 0.824039 & 0.113801 \\
\hline
\end{tabular}

Source: Authors' Computation

Note: Restrictions are linear in coefficients.

Table 7. Wald Causality Test for Model Two 